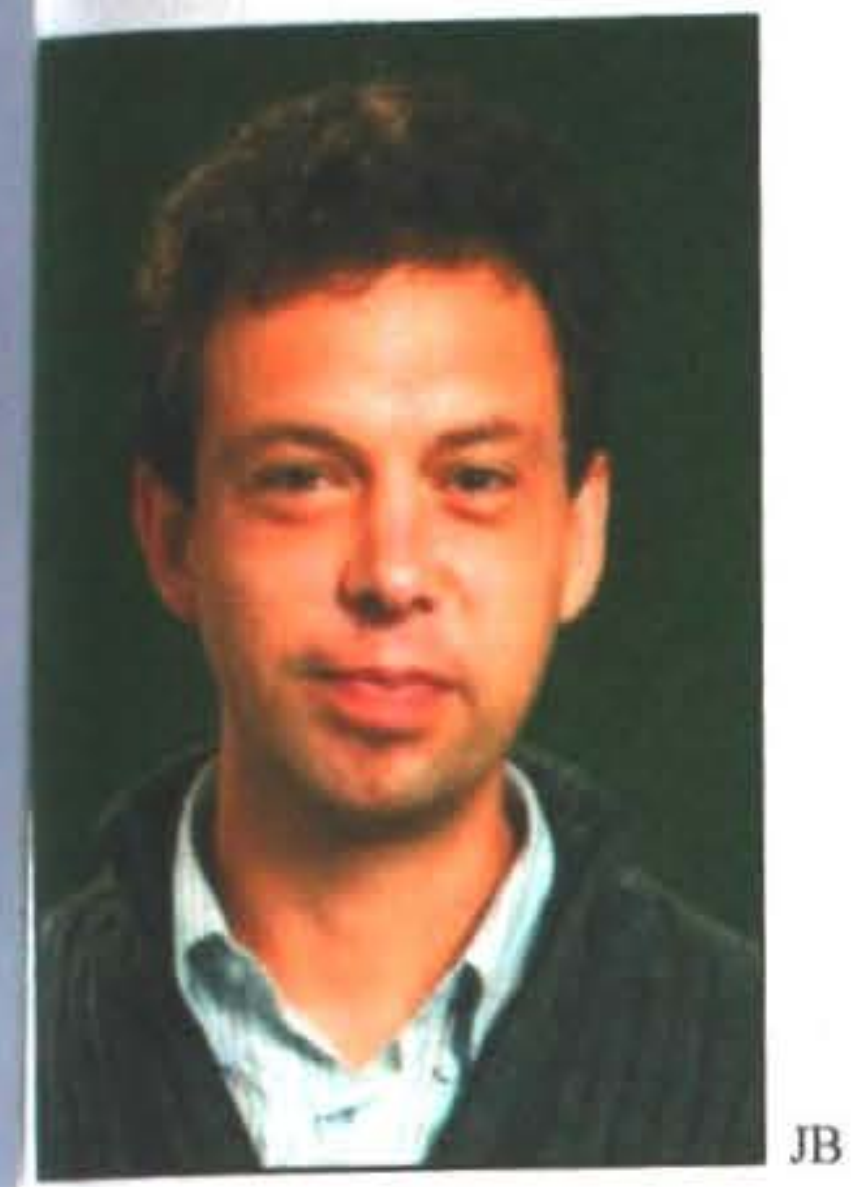

\title{
REASONS FOR MIGRATING AND SETTLEMENT OUTCOMES: EVIDENCE FROM THE LONGITUDINAL IMMIGRATION SURVEY NEW ZEALAND
}

\author{
John Bryant \\ Statistics New Zealand \\ Paul Merwood
}

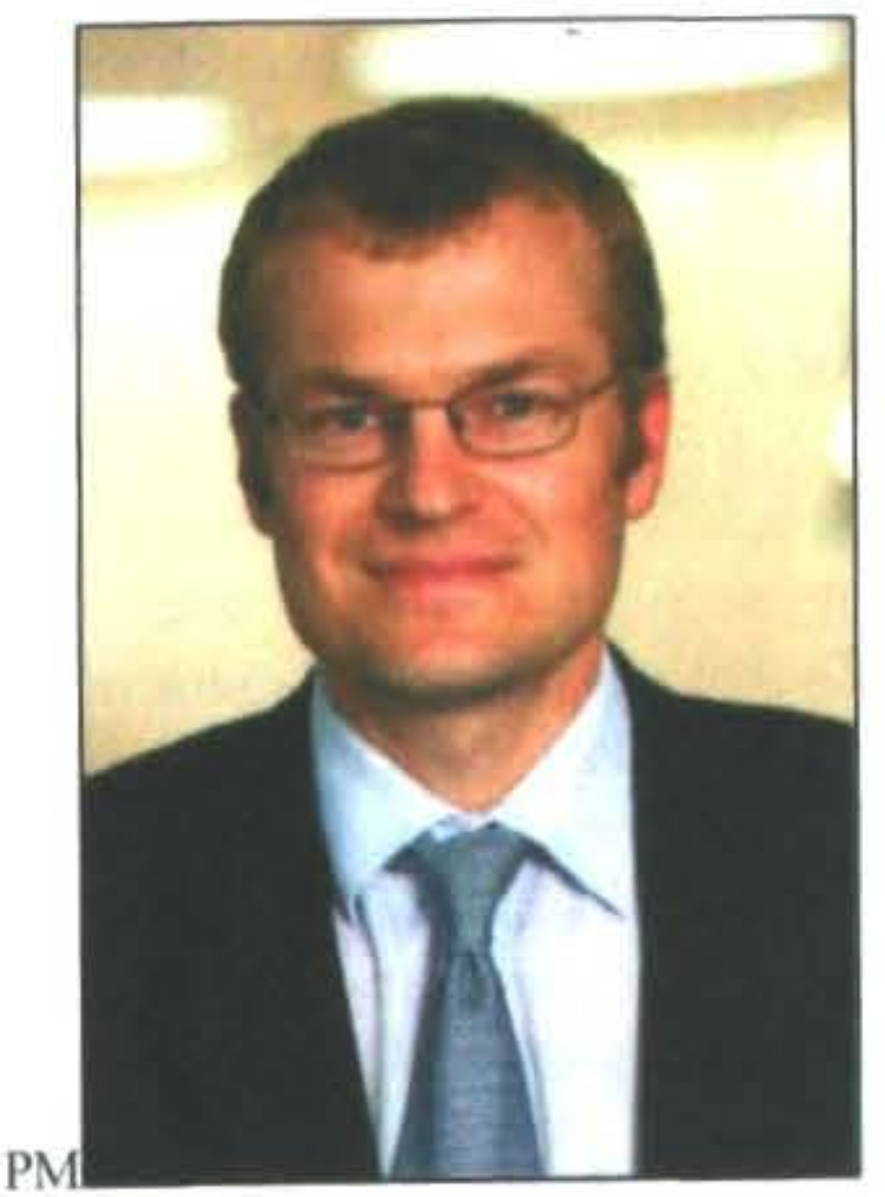

New Zealand Department of Labour

\begin{abstract}
People migrate internationally for many different reasons: some want a better lifestyle, for instance, while some want better employment opportunities. The Longitudinal Immigration Survey: New Zealand (LisNZ) presents a rare opportunity to study the relationship between reasons for migrating, background characteristics, and settlement outcomes. We use correlations between responses to group reasons into five main categories. We examine how migrants' social and demographic profiles differ according to their reasons for migrating. We then examine whether migrants with different reasons for migrating experience different settlement outcomes at six months after residence approval. Among other things, we find that lifestyle migrants are particularly likely to be satisfied with life in New Zealand.
\end{abstract}

\section{Introduction}

People have many reasons for moving to a new country: advancing a career, following a spouse, attending university, and much else besides. Different reasons for migrating are likely to be associated with different outcomes. Predicting outcomes from reasons is, however, difficult. Do 'career' migrants find jobs more quickly or less quickly than other migrants? Do 'lifestyle' migrants work less hard, or harder, than other migrants?

Reasons for migrating feature in many streams of migration research. For instance, people's desire to migrate to areas with natural amenities explains why employers in these areas can pay lower wages but still attract workers (Roback 1982, Glaeser 2007). Research building on Mincer (1978) has shown how family ties can encourage or impede labour migration. Some researchers claim that migrants have distinct personality traits (Boneva 2001). But, with some exceptions (eg Schellenberg and Maheux 2007), empirical studies linking individuals' reasons for migration to their subsequent outcomes are rare, possibly because these sorts of analyses require longitudinal datasets with questions on reasons and on social and economic outcomes.

The Longitudinal Immigration Survey: New Zealand (LisNZ) is one of the few datasets internationally that has the required data. Our paper takes advantage of the LisNZ data to explore migrants' motivations for coming to New Zealand, and to examine how these motivations correlate with settlement outcomes.
At the time of writing, only data from wave 1 of LisNZ have been released. This means that we are able to look only at outcomes six months after residence approval. In future work will use data from later waves to examine longer-term outcomes.

The paper is organized as follows. Section 2 gives a brief overview of LisNZ. Section 3 presents data on reasons for coming to New Zealand, and shows how the reasons can be grouped into five categories. Section 4 looks at how the background characteristics of migrants differ across these categories. Section 5 examines the relationship between category of reason and migration outcomes, with and without controls for background characteristics such as age, sex, and region of origin. The final section summarizes the main findings and discusses future research.

\section{The Longitudinal Immigration Survey: New Zealand (LisNZ)}

The LisNZ is designed to trace the pathways of migrants and to produce detailed information on migrants and their settlement outcomes. Migrants are interviewed at six, 18 and 36 months after they have taken up permanent residence in New Zealand. The LisNZ is a partnership between Statistics New Zealand and the Department of Labour.

The survey sample was selected from migrants who were approved for residence in New Zealand from 1 November 2004 to 31 October 2005. The target population for 
LisNZ consists of all migrants aged 16 and over who were granted permanent residence, excluding Australians, (who are automatically entitled to residence in New Zealand) and refugees. The total sample of migrants for wave 1 , including both onshore and offshore applicants, for 7,137 .

People who wish to migrate permanently to New Zealand must apply through one of the streams of the New Zealand Residence Programme (NZRP). The streams are Skilled/Business, the Family Sponsored Stream and the International/Humanitarian Stream, which includes migrants coming through specific agreements with countries in the Pacific. In addition there is an uncapped Immediate Family Category for partners and dependent children. Each stream contains various categories or immigration policies. An application for permanent residence includes the principal applicant and any secondary applicants (for example, a partner and children). All people in the application are approved through the same policy, such as the Skilled Migrant Category (SMC). In this paper, the various migration categories have been grouped into four broad classes: Skilled, Family, Business, and Pacific and Other.

\section{Data on Reasons for Migrating}

Data on reasons for migrating were collected with the following prompt:

\section{People choose to move to a new country for different reasons. Please look at card A25 and tell me the main reasons why you decided to apply for New Zealand residence.}

Respondents were presented with a show card with the options listed in Table 1 (plus a category 'other - please specify'). Respondents were allowed to nominate more than one reason for migrating. This is an important strength of the LisNZ data. Migration affects many aspects of people's lives, and migrants typically have more than one objective when moving. Allowing multiple reasons permits at least some of this complexity to be captured. When censuses and general-purpose surveys ask about migration, they typically force respondents to select a single reason.

\section{Table 1: Reasons for migrating}

\begin{tabular}{lc}
\hline Reason & $\begin{array}{c}\text { Percent } \\
\text { citing }\end{array}$ \\
\hline Marry or live with a NZ spouse or partner & 16 \\
Join family members & 23 \\
Accompany family members & 7 \\
A better future for my children & 39 \\
Employment opportunities & 28 \\
Economic conditions & 13 \\
Political stability & 15 \\
Safety from crime & 27 \\
Educational opportunities & 18 \\
To study & 10 \\
Climate or the clean, green environment & 40 \\
Relaxed pace of life or lifestyle & 44 \\
Easy access to outdoor or sporting activities & 22 \\
Friendly people & 28 \\
\hline
\end{tabular}

Table 1 shows the percentage of respondents selecting each of 14 reasons. Respondents averaged more than three reasons each, so the percentages add up to over 300 . The two most commonly-cited reasons are both related to lifestyle and natural amenities, reflecting New Zealand's status as a 'high amenity' destination, like Australia or the US West Coast. Nevertheless, substantial numbers of migrants also have other motivations, including employment opportunities and safety from crime.

Reasons are correlated with one another. For instance, a migrant who chose 'relaxed pace of life or lifestyle' was more likely to choose 'climate or the clean, green environment', and less likely to choose 'employment opportunities'. These correlations can be used to sort reasons into groups. Because they incorporate information from the pattern of responses, these groups do not necessarily match the ones that the questionnaire designers had in mind.

The data reduction is carried out by extracting the first two 'principal components' of the covariance matrix for responses (Venables and Ripley 2002: 302-5). The 14 sets of 14 numbers that perfectly describe the correlations between reasons are reduced to 14 sets of two numbers that approximately describe the correlations. Going from sets of 14 numbers to sets of two entails a loss of information, but it also means that relationships between the reasons can be represented in a two-dimensional plot, such as Figure 1.

Figure 1: Principal components analysis of data on reasons for migrating

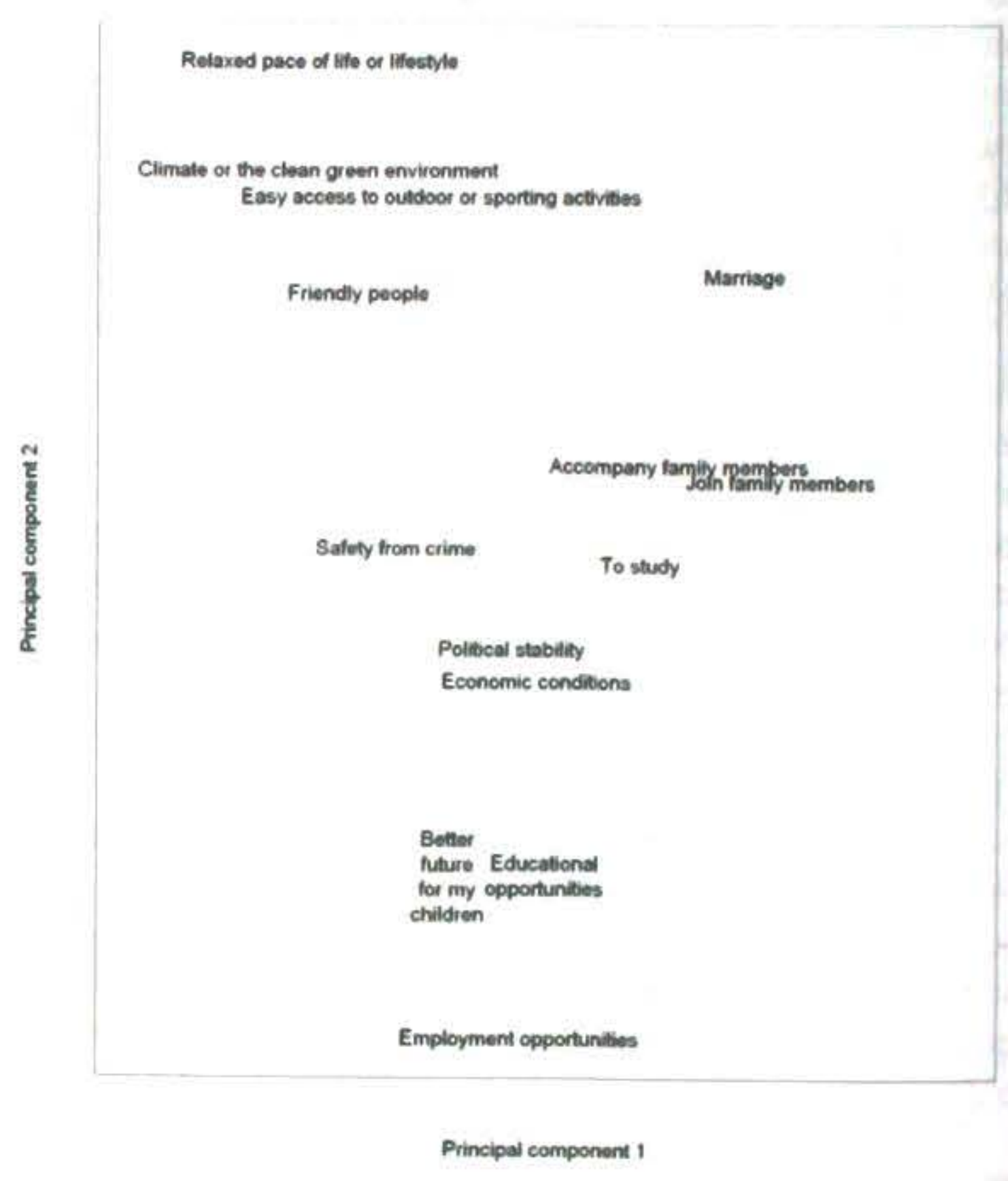

Reasons that lie close to each other in Figure 1 are more likely to be mentioned together than reasons that lie far apart. The dotted lines identifying groups of reasons were added by us. In some cases, our choices were informed by 
our understanding of the meaning of the questions. For instance, we put 'To study' into a category of its own, despite the fact that it is closer to 'Accompany family members' and 'Join family members' than 'Marriage' is, because migrating to study is not a type of family migration.

Table 2 shows the categories identified in Figure 1, together with our labels for each category, and the percentage of respondents who chose at least one reason from that category. A respondent could choose reasons from more than one category, so the percentages add up to more than 100 . Slightly more respondents chose one of the 'opportunities' reasons than chose one of the 'lifestyle' reasons.

Table 2: Categories of reasons

\begin{tabular}{|c|c|c|}
\hline Category & Reasons & $\begin{array}{l}\text { Percent } \\
\text { choosing }\end{array}$ \\
\hline Opportunities & $\begin{array}{l}\text { A better future for my children } \\
\text { - Employment opportunities } \\
\text { - Educational opportunities }\end{array}$ & 59 \\
\hline Lifestyle & $\begin{array}{l}\text { - Relaxed pace of life or lifestyle } \\
\text { - Climate or the clean, green } \\
\text { environment } \\
\text { - Easy access to outdoor or } \\
\text { sporting activities } \\
\text { - Friendly people }\end{array}$ & 57 \\
\hline Family & $\begin{array}{l}\text { - Marry or live with a NZ spouse } \\
\text { or partner } \\
\text { - Accompany family members } \\
\text { - Join family members }\end{array}$ & 42 \\
\hline Security & $\begin{array}{l}\text { - Safety from crime } \\
\text { - Political stability } \\
\text { - Economic conditions }\end{array}$ & 37 \\
\hline Study & To study & 10 \\
\hline
\end{tabular}

\section{Characteristics of Migrants by Reasons for Migrating}

People with different motives for migrating can be expected to differ in other ways as well. Table 3 shows some summary statistics for respondents nominating reasons from each of the categories identified in the previous section. Many respondents gave reasons from more than one category, so the same migrant can, for instance, be an 'opportunity' migrant and a 'security' migrant. 'Has partner' in Table 3 means that the respondent had a spouse or partner at the time of residence approval. 'Has child' means that a respondent had a dependent child in his or her residence application. Respondents with 'good English' stated that English was their main language, or that they spoke it well.

The most distinctive group in Table 3 is the smallest one, those who migrated to New Zealand to study. These people tend to be younger than other migrants, and are more likely to come from North Asia. The best-educated group is lifestyle migrants. The group with the highest ratio of females to males is family migrants. Many British and Irish come New Zealand for lifestyle reasons, while many South Africans come for security reasons.

Table 3: Characteristics of respondents by reasons for migrating

\begin{tabular}{|c|c|c|c|c|c|}
\hline & Opportunities & Lifestyle & Family & Secur-ity & Study \\
\hline Female $(\%)$ & 48 & 48 & 59 & 46 & 53 \\
\hline Mean age & 35.1 & 36.2 & 37.1 & 36.4 & 26.7 \\
\hline Mean years of schooling & 14.8 & 15.0 & 13,7 & 14.9 & 14.6 \\
\hline Has partner $(\%)$ & 78 & 79 & 71 & 81 & 47 \\
\hline Has child $(\%)$ & 48 & 38 & 19 & 44 & 14 \\
\hline In NZ when residence approved (\%) & 72 & 72 & 67 & 74 & 83 \\
\hline Good English (\%) & 90 & 92 & 79 & 93 & 86 \\
\hline \multicolumn{6}{|l|}{ Origin (\%) } \\
\hline UK \& Ireland & 32 & 44 & 25 & 35 & 5 \\
\hline South Africa & 11 & 7 & 7 & 16 & 7 \\
\hline N America \& Europe & 9 & 11 & 11 & 9 & 6 \\
\hline North Asia & 16 & 18 & 18 & 14 & 44 \\
\hline South Asia & 8 & 6 & 10 & 6 & 11 \\
\hline SE Asia & 5 & 5 & 7 & 5 & 7 \\
\hline Pacific & 14 & 5 & 18 & 9 & 17 \\
\hline Other & 5 & 3 & 4 & 6 & 4 \\
\hline \multicolumn{6}{|l|}{ Approval category (\%) } \\
\hline Skilled & 69 & 73 & 28 & 74 & 57 \\
\hline Family & 17 & 18 & 61 & 16 & 25 \\
\hline Business & 7 & 6 & 4 & 5 & 10 \\
\hline Pacific \& Other & 8 & 3 & 7 & 5 & 8 \\
\hline $\mathrm{N}$ - unweighted & 4,350 & 3,830 & 3,130 & 2,530 & 840 \\
\hline $\mathrm{N}$ - weighted & 21,430 & 20,780 & 15,390 & 13,250 & 3,700 \\
\hline
\end{tabular}




\section{The Relationship Between Reasons for Migrating and Settlement Outcomes}

Figure 2 shows how settlement outcomes vary according to reasons for migrating. All outcomes are measured at six months after residence approval. The first outcome is whether the respondent is in full or part time employment. The second is whether the respondent has received any benefits or payments from the New Zealand government. The third is whether the respondent belongs to any clubs or associations in New Zealand; this is an indicator of social integration. The fourth is whether the migrant said they were 'very satisfied' when asked about their overall level of satisfaction with living in New Zealand.

Figure 2: Settlement outcomes, by reason for migrating

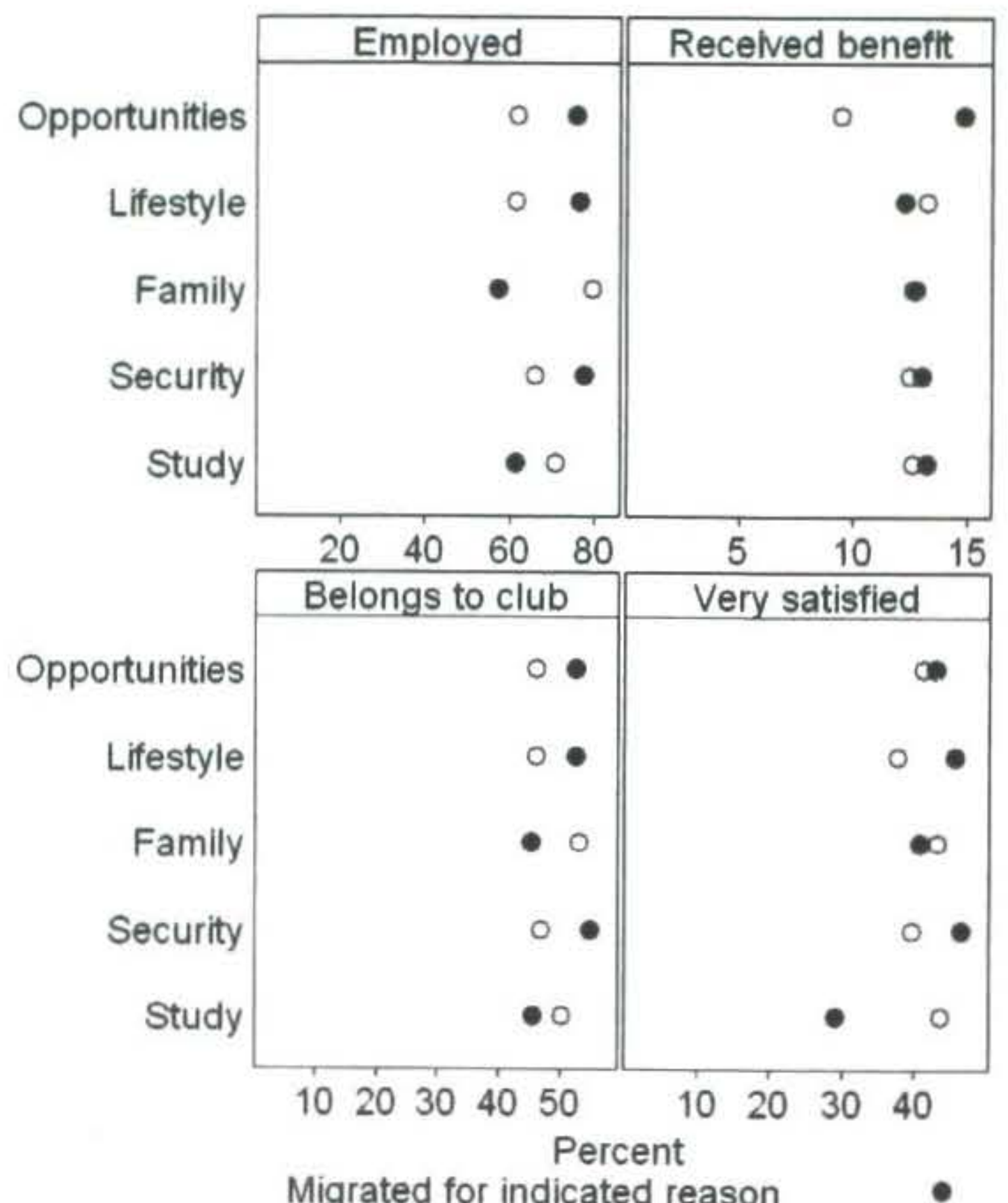

Did not migrate for indicated reason

Figure 2 is a 'dot chart': the dots convey the same information as the ends of the bars in a horizontal bar chart (Cleveland 1994: 150-4). The dot chart

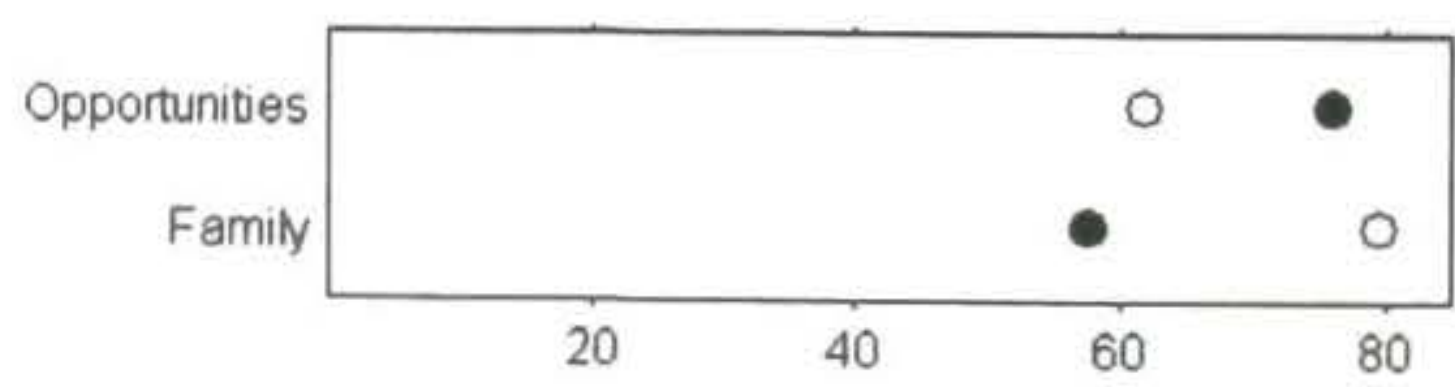

is equivalent to the bar chart

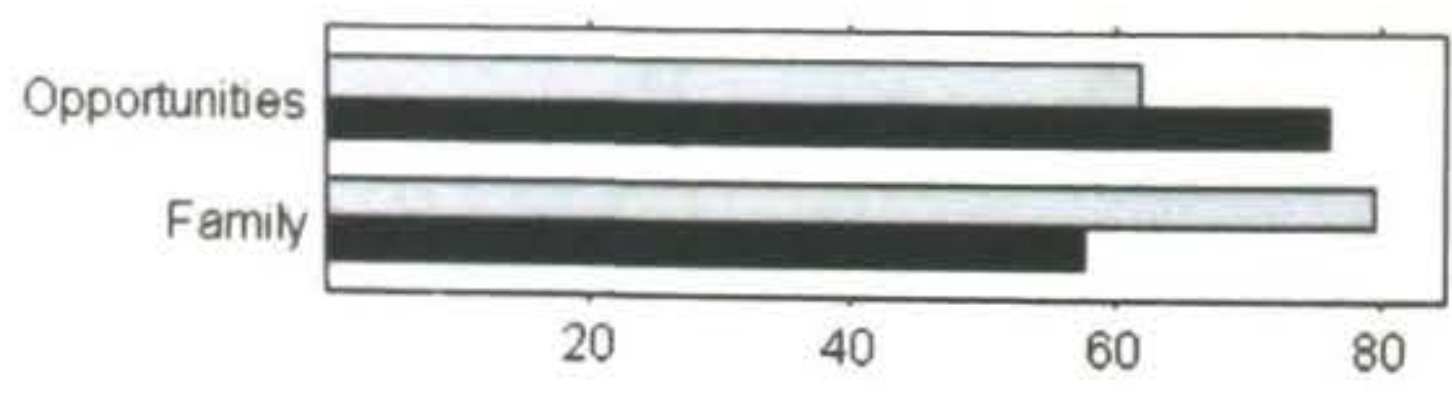

but with less clutter. The solid dots in Figure 2 show outcomes for people who cited each reason, and the hollow dots shows outcomes for people who did not. For instance, the pair of dots at the top of the 'employed' panel indicate that 76 percent of migrants who gave an 'opportunities' reason for coming to New Zealand were employed, while only 62 percent of those who did not give an opportunities reason were employed. The horizontal scales differ between panels, though all start at zero.

People coming to New Zealand for opportunities, lifestyle, and security reasons have above-average employment rates, while those coming for family reasons or study have below-average rates. All these results are predictable, except, perhaps the results for lifestyle migrants. Results for belonging to a club resemble the results for employment. Coming to New Zealand for opportunities is associated with greater benefit use. Migration for lifestyle or security is associated with relatively high satisfaction ratings, and migration for study relatively low ratings.

The pattern of outcomes apparent in Figure 2 reflects differences in respondents' reasons for migrating, but also differences in background characteristics. A purer measure of the influence of reasons for migrating can be obtained by imposing a model on the data, and statistically controlling for differences in characteristics. Controlling for a small number of observed characteristics is not sufficient to establish causation. But it is a first step in that direction.

Table 4 shows results from statistical models predicting the outcomes in the Figure 2. The models all use logistic regression, to allow for the fact that the outcomes are all yes-no variables. Some of the coefficient estimates for the control variables in Table 4 are interesting. For instance, having good English and having residence approved onshore are associated with higher employment, lower benefit use, higher membership of clubs and higher overall satisfaction. But, for present purposes, the main interest of Table 4 lies in the coefficient estimates on reasons for migrating.

As can be seen from the coefficient estimates in Table 4, controlling for background characteristics eliminates the negative relationship between employment and migrating for opportunities and security. However, the negative relationship with family or study migration remains, as does the positive relationship with lifestyle migration. Benefits use continues to be positively associated with opportunities migration. All the associations between joining a club and reasons for migration disappear, except for the positive association between joining a club and being a lifestyle migrant. The strong negative association between satisfaction and migration for study disappears, but the positive associations between satisfaction and lifestyle and security migration remains.

Knowing the direction and statistical significance of associations between reasons and outcomes is useful, but it is also helpful to have some sense of the magnitudes. 
For instance, it is helpful to know whether the difference in satisfaction levels between lifestyle and non-lifestyle migrants is big enough to have any substantive significance. Assessing substantive significance is difficult with logistic regression, because the relationship between response and explanatory variables is complicated.

The standard solution is to translate the coefficient estimates into hypothetical scores on the response variable. Figure 3 is one such translation. The dots in Figure 3 have the same meaning as those in Figure 2, except that they now refer to hypothetical populations that are identical in all ways except for reasons for migrating. (More precisely, each dot was obtained by calculating predicted responses for everyone in the sample, given actual values on all explanatory variables except for the reasons variables, which were set to 1 for the solid dots, and 0 for the hollow dots.)

Table 4: Determinants of probability of being employed, receiving benefit, belonging to a club, and being very satisfied with living in New Zealand

\begin{tabular}{|c|c|c|c|c|}
\hline & Employed & Received benefit & Belongs to club & Very satisfied \\
\hline \multicolumn{5}{|l|}{ Reason for migrating } \\
\hline Opportunities & $\begin{array}{c}0.135 \\
(0.073)\end{array}$ & $\begin{array}{l}0.272 * * \\
(0.093)\end{array}$ & $\begin{array}{c}0.090 \\
(0.061)\end{array}$ & $\begin{array}{c}-0.089 \\
(0.065)\end{array}$ \\
\hline Lifestyle & $\begin{array}{l}0.158^{*} \\
(0.072)\end{array}$ & $\begin{array}{c}0.032 \\
(0.085)\end{array}$ & $\begin{array}{c}0.297^{* * *} \\
(0.059)\end{array}$ & $\begin{array}{c}0.232^{* * *} \\
(0.063)\end{array}$ \\
\hline Family & $\begin{array}{c}-0.576^{* * *} \\
(0.069)\end{array}$ & $\begin{array}{c}0.109 \\
(0.083)\end{array}$ & $\begin{array}{c}-0.103 \\
(0.058)\end{array}$ & $\begin{array}{c}0.059 \\
(0.061)\end{array}$ \\
\hline Security & $\begin{array}{c}0.141 \\
(0.075)\end{array}$ & $\begin{array}{c}-0.046 \\
(0.086)\end{array}$ & $\begin{array}{c}0.001 \\
(0.059)\end{array}$ & $\begin{array}{l}0.128^{*} \\
(0.062)\end{array}$ \\
\hline Study & $\begin{array}{c}-0.492 * * * \\
(0.096)\end{array}$ & $\begin{array}{c}0.145 \\
(0.118)\end{array}$ & $\begin{array}{c}0.035 \\
(0.082)\end{array}$ & $\begin{array}{c}-0.071 \\
(0.091)\end{array}$ \\
\hline Female & $\begin{array}{c}-1.095 * * * \\
(0.064)\end{array}$ & $\begin{array}{l}0.180^{*} \\
(0.073)\end{array}$ & $\begin{array}{c}-0.146^{* *} \\
(0.050)\end{array}$ & $\begin{array}{c}-0.163^{* *} \\
(0.053)\end{array}$ \\
\hline \multicolumn{5}{|l|}{ Age } \\
\hline $16-29$ & [ref] & [ref] & [ref] & [ref] \\
\hline $30-44$ & $\begin{array}{c}0.380^{* * * *} \\
(0.082)\end{array}$ & $\begin{array}{c}0.158 \\
(0.099)\end{array}$ & $\begin{array}{l}0.216^{* *} \\
(0.067)\end{array}$ & $\begin{array}{c}0.107 \\
(0.071)\end{array}$ \\
\hline $45-64$ & $\begin{array}{c}-0.241^{*} \\
(0.097)\end{array}$ & $\begin{array}{c}-0.328^{*} \\
(0.135)\end{array}$ & $\begin{array}{c}0.342^{* * *} \\
(0.085)\end{array}$ & $\begin{array}{l}0.219^{*} \\
(0.089)\end{array}$ \\
\hline $64+$ & $\begin{array}{c}-3.009 * * * \\
(0.266)\end{array}$ & $\begin{array}{c}-0.105 \\
(0.236)\end{array}$ & $\begin{array}{l}0.309^{*} \\
(0.151)\end{array}$ & $\begin{array}{l}0.423^{* *} \\
(0.155)\end{array}$ \\
\hline Has partner & $\begin{array}{c}0.101 \\
(0.077)\end{array}$ & $\begin{array}{c}0.457^{* * * *} \\
(0.102)\end{array}$ & $\begin{array}{c}-0.081 \\
(0.063)\end{array}$ & $\begin{array}{c}-0.115 \\
(0.068)\end{array}$ \\
\hline Has child & $\begin{array}{c}-0.203^{*} \\
(0.081)\end{array}$ & $\begin{array}{c}0.323^{* * * *} \\
(0.091)\end{array}$ & $\begin{array}{c}-0.054 \\
(0.065)\end{array}$ & $\begin{array}{c}-0.186^{* *} \\
(0.068)\end{array}$ \\
\hline Years of schooling & $\begin{array}{c}0.089^{* * * *} \\
(0.011)\end{array}$ & $\begin{array}{c}-0.020 \\
(0.012)\end{array}$ & $\begin{array}{c}0.060^{* * *} \\
(0.008)\end{array}$ & $\begin{array}{c}-0.023^{* *} \\
(0.009)\end{array}$ \\
\hline In NZ when residence approved & $\begin{array}{c}0.905^{* * *} \\
(0.071)\end{array}$ & $\begin{array}{c}-0.003 \\
(0.086)\end{array}$ & $\begin{array}{c}0.431^{* * * *} \\
(0.060)\end{array}$ & $\begin{array}{l}0.175 * * \\
(0.062)\end{array}$ \\
\hline Good English & $\begin{array}{c}0.348^{* * *} \\
(0.095)\end{array}$ & $\begin{array}{c}-0.294^{* *} \\
(0.113)\end{array}$ & $\begin{array}{l}0.195^{*} \\
(0.085)\end{array}$ & $\begin{array}{c}0.117 \\
(0.095)\end{array}$ \\
\hline \multicolumn{5}{|l|}{ Origin } \\
\hline \multirow{2}{*}{ South Africa } & [ref] & [ref] & [ref] & [ref] \\
\hline & $\begin{array}{c}-0.094 \\
(0.157)\end{array}$ & $\begin{array}{c}-0.042 \\
(0.200)\end{array}$ & $\begin{array}{c}0.557^{* * * *} \\
(0.122)\end{array}$ & $\begin{array}{c}-0.085 \\
(0.118)\end{array}$ \\
\hline N America \& Europe & $\begin{array}{c}-0.216 \\
(0.133)\end{array}$ & $\begin{array}{c}0.072 \\
(0.176)\end{array}$ & $\begin{array}{l}-0.049 \\
(0.105)\end{array}$ & $\begin{array}{c}-0.155 \\
(0.104)\end{array}$ \\
\hline North Asia & $\begin{array}{c}-0.794^{* * * *} \\
(0.113)\end{array}$ & $\begin{array}{l}0.294^{*} \\
(0.143)\end{array}$ & $\begin{array}{c}-0.606 * * * \\
(0.093)\end{array}$ & $\begin{array}{c}-2.084^{* * *} \\
(0.111)\end{array}$ \\
\hline \multirow[t]{2}{*}{ South Asia } & -0.222 & $0.730^{* * *}$ & $-0.413^{* * *}$ & $-1.079 * * *$ \\
\hline & $(0.121)$ & $(0.136)$ & $(0.093)$ & $(0.097)$ \\
\hline SE Asia & $\begin{array}{c}0.070 \\
(0.126)\end{array}$ & $\begin{array}{c}0.118 \\
(0.155)\end{array}$ & $\begin{array}{c}0.119 \\
(0.096)\end{array}$ & $\begin{array}{c}-1.030^{* * *} \\
(0.100)\end{array}$ \\
\hline \multirow[t]{2}{*}{ Pacific } & 0.065 & $0.753^{* * *}$ & $0.373^{* * *}$ & $-0.336 * * *$ \\
\hline & $(0.111)$ & $(0.130)$ & $(0.089)$ & $(0.090)$ \\
\hline Other & -0.273 & $0.574^{* * * *}$ & $0.336^{* *}$ & $-0.515 * * *$ \\
\hline \multirow[b]{2}{*}{ (Intercept) } & $(0.148)$ & $(0.163)$ & $(0.115)$ & $(0.113)$ \\
\hline & $\begin{array}{c}-0.330 \\
(0.202)\end{array}$ & $\begin{array}{c}-2.562 * * * \\
(0.247)\end{array}$ & $-1.518^{* * *}$ & $\begin{array}{c}0.314 \\
(0.177)\end{array}$ \\
\hline McFadden $\mathrm{R}^{2}$ & $\frac{(0.202)}{0.197}$ & $\begin{array}{c}(0.247) \\
0.040\end{array}$ & $\begin{array}{c}(0.171) \\
0.047\end{array}$ & $\frac{(0.177)}{0.089}$ \\
\hline Log-likelihood & -3399.5 & -2658.3 & -4692.5 & -4308.8 \\
\hline Deviance & 6799.0 & 5316.6 & 9385.0 & 8617.7 \\
\hline $\mathrm{N}$ & 7,101 & 7,096 & 7,101 & 7,099 \\
\hline
\end{tabular}

Notes. [ref] denotes reference category. *significant at $5 \%$ level. $* *$ significant at $1 \%$ level. ${ }^{* * *}$ significant at $0.1 \%$ level 
Figure 3: Hypothetical settlement outcomes, by reason for migrating, based on results from Table 4

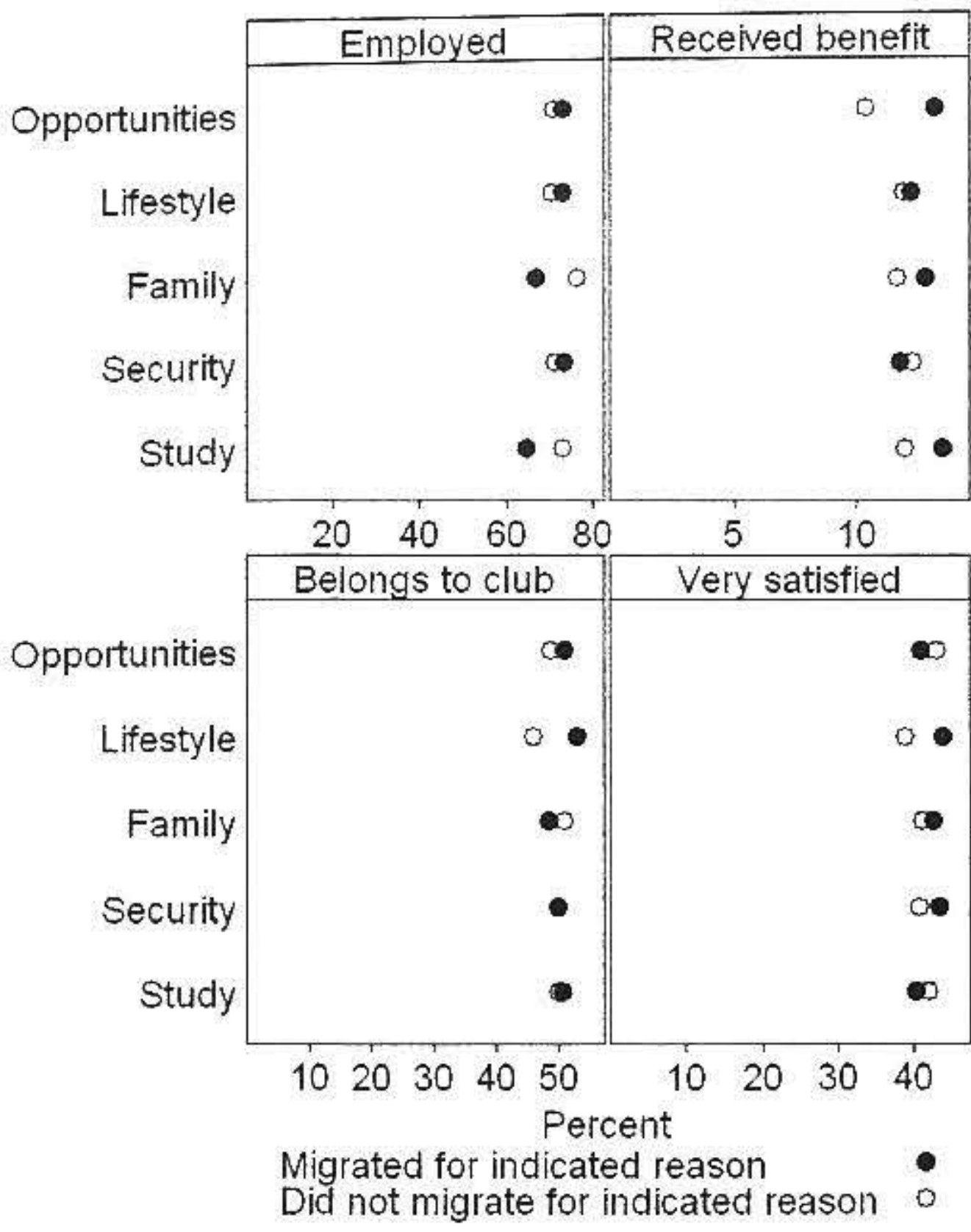

As can be seen by comparing Figure 3 with Figure 2, controlling for differences in background characteristics reduces most of the differences in outcomes to negligible levels. However, some substantively significant gaps remain. For instance, there is still a pronounced tendency for lifestyle migrants to join a club and be more satisfied with life in New Zealand.

We tested the robustness of these results by re-estimating the models separately for UK migrants and Asian migrants. Most of the results were essentially unchanged. Perhaps the most notable exception was that, among migrants from Asia, people migrating for family reasons rather than lifestyle reasons were the ones most likely to be very satisfied with life in New Zealand.

\section{Conclusions}

\section{Main Findings}

Common sense suggests that people migrating for different reasons will have different characteristics and will experience different settlement outcomes. LisNZ offers a good opportunity to test these assumptions. This paper presents some basic analyses, focussing on background characteristics and short-term outcomes.

The paper shows how, using a principal components analysis and some subjective judgement, the detailed data on reasons for migrating can be reduced to more manageable proportions. Migrants coming to New Zealand for different reasons do indeed have different profiles for basic variables such as age, sex, education, and nationality, even when there is a great deal of overlap between groups giving different reasons. There are also differences in settlement outcomes at six months, with and without statistical controls for observed differences in background characteristics. In particular, migrants coming to New Zealand for family reasons or to study have lower employment rates, migrants coming for opportunities are slightly more likely to have drawn a benefit, and lifestyle migrants are more likely to have joined a club and to be very satisfied with life in New Zealand.

\section{Future Work}

Data from interviews at 18 months and 36 months after residence approval will allow us to extend the analysis to somewhat longer-term settlement outcomes. We will be able to test whether observed differences grow or shrink as migrants pursue their varying objectives. Moving from cross-sectional to panel data will also provide opportunities to control for unobserved differences in background characteristics, and hence obtain purer measures of the relationship between reasons for migrating and settlement outcomes.

\section{References}

Boneva, B. S. and Frieze, I. H. (2001) Toward a concept of a migrant personality. Journal of Social Issues 57, 477-491.

Cleveland, W. (1993) Visualizing Data. Summit: Hobart Press

Glaeser. E. L. (2007) The Economic Approach to Cities. Harvard University and NBER

Mincer, J. (1978) Family Migration Decisions. Journal of Political Economy 86, 749-773.

Roback, J. (1982) Wages, Rents, and the Quality of Life. Journal of Political Economy, 90, 1257-1278.

Schellenberg, G. Maheux, H. (2007) Immigrants: perspectives on their first four years in Canada: Highlights from three waves of the Longitudinal Survey of Immigrants to Canada. Canadian Social Trends 11, 1-34.

Venables, W. N. and Ripley, B. D. (2002) Modern Applied Statistics with S. Fourth Edition. New York: Springer.

\section{Authors}

John Bryant

Statistics New Zealand

Statistics House

The Boulevard

Harbour Quays

PO Box 2922

Wellington 6140

John.Bryant@stats.govt.nz

Paul Merwood

Research Analyst

Workforce Research and Evaluation

Department of Labour

P.O. Box3705

Wellington

Paul.Merwood@dol.govt.nz 